\title{
Stratigraphy, paleoenvironmental evolution and regional significance of the Silurian Lake Ayımer-Lake Saint-François belt, Eastern Townships, Québec
}

\author{
Denis Lavoie* and Pierre-André Bourque \\ Groupe Interuniversitaire de Recherches Géologiques en Analyse de Bassin, Université Laval, \\ Ste-Foy, Québec G1K 7P4, Canada \\ Date Received January 7, 1992 \\ Date Accepted August 25, 1992
}

\begin{abstract}
Upper Silurian rocks outcrop in a relatively narrow belt centered on Lake Aylmer in the Eastern Townships of southern Québec. Two distinct lithotectonic units form this belt. The Lac Aylmer Formation is a $1200 \mathrm{~m}$-thick autochthonous unit, lying with disconformity over the Middle-Upper Ordovician Magog Group. The Lac Lambton Formation is a $1100 \mathrm{~m}$-thick unit unconformably overlying the Middle Ordovician or older Ascot Complex. The Lac Lambton Formation is part of an allochthonous succession, transported northwestward during the Acadian orogeny along the La Guadeloupe fault. The Lac Aylmer Formation comprises a lower conglomeratic member, a middle sandstone/siltstone member and an upper mixed fine-grained, siliciclastic carbonate member with local reefoid limestone masses. The Lac Lambton Formation is divided into eight informal members, collectively comprising conglomerates, carbonates and fine-grained siliciclastics. The upper parts of both formations have yielded Pridolian (Late Silurian) brachiopods. Field and petrographic studies of the various conglomerates have shown that they share a clast source (the Ascot Complex) but were deposited in dissimilar environments. The two formations were part of distinct depositional basins separated by an emergent topographic element, the Ascot Complex. The lack of detailed biostratigraphic data for most parts of the units raises the possibility that the basal disconformity/unconformity could be either Taconic (Late Ordovician) or Salinic (Late Silurian).
\end{abstract}

Les roches du Silurien supérieur affleurent le long d'une bande relativement mince centrée sur le lac Aylmer en Estrie, dans le sud du Québec. Deux unités lithotectoniques distinctes forment cette bande. La Formation du Lac Aymer est une unité autochtone de $1200 \mathrm{~m}$ d'épaisseur reposant en inconformité sur le Groupe de Magog, d'âge Ordovicien moyen à supérieur. La Formation du Lac Lambton est une unité de $1100 \mathrm{~m}$ d'épaisseur qui recouvre en discordance ce le Group d'Ascot, d'âge Ordovicien moyen ou plus ancie. La Formation du Lac Lambton fait partie d'une succession allochtone, transportée vers le nord-ouest durant l'orogénèse acadienne le long de la faille de la Guadeloupe. La Formation du Lac Aylmer comprend un membre conglomératique inférieur, un membre intermédiaire de grès-siltstone et un membre supérieur mélangé de carbonates et de silicoclastites à grain fin avec localement des masses de calcaires d'allure récifale. La Formation du Lac Lambton est divisée en huit membres informels, comprenant des conglomérats, des carbonates et des silicoclastites à grain fin. Les parties supérieures des deux formations contiennent des brachiopodes pridoliens (Silurien tardif). Les études de terrain et pétrographiques des divers conglomérats ont montré qu 'ils partagent une source de clastes (le Complexe d'Ascot) mais furent déposés dans des milieux différents. Les deux formations faisaient partie de bassins de déposition distincts séparés par un élément topographique émergent, le Complexe d'Ascot. Le manque de données biostratigraphiques détaillées pour la plupart des unités laisse ouverte la possibilité que disconformité/discordance de base soit taconique (Ordovicien supérieur) ou Salinique (Silurien supérieur).

\section{INTRODUCTION}

The post-Taconian rocks of the Québec and New Brunswick Appalachians are divided into four temporal and lithological assemblages (Malo and Bourque, in press). These are: (1) Upper Ordovician - lowermost Silurian deep water, finegrained, siliciclastic and carbonate units (Honorat, Grog Brook, Cabano, and Matapédia groups); (2) Silurian - lowermost Devonian shallow to deep shelf facies (Chaleurs Group and equivalents, lower part of Saint-Francis Group); (3)

*Present Address: Geological Survey of Canada, Centre Géoscientifique de Québec, 2700 Einstein Street, P.O. Box 7500, SteFoy, Québec G1V 4C7, Canada
[Traduit par le journal]

Lower Devonian, fine-grained, deep-shelf, mixed siliciclastic and carbonate units (Upper Gaspé Limestones, Fortin and Témiscouata groups, and the upper part of the Saint-Francis Group); (4) uppermost Lower to Upper Devonian, nearshore to terrestrial, coarse-grained siliciclastic units (Gaspe Sandstones Group). These assemblages represent infills of postTaconian successor basins developed over the Dunnage Zone, south of the Baie Verte-Brompton Line (Tremblay, 1992a). The four packages occur in three main structural units; the Connecticut Valley-Gaspé Synclinorium, the Aroostook-Percé Anticlinorium, and the Chaleurs Bay Synclinorium (Fig. 1).

Only in the Gaspe Belt (Bourque et al., in press) is the complete succession developed, and there its stratigraphy, structural geology, depositional environments and paleogeo- 


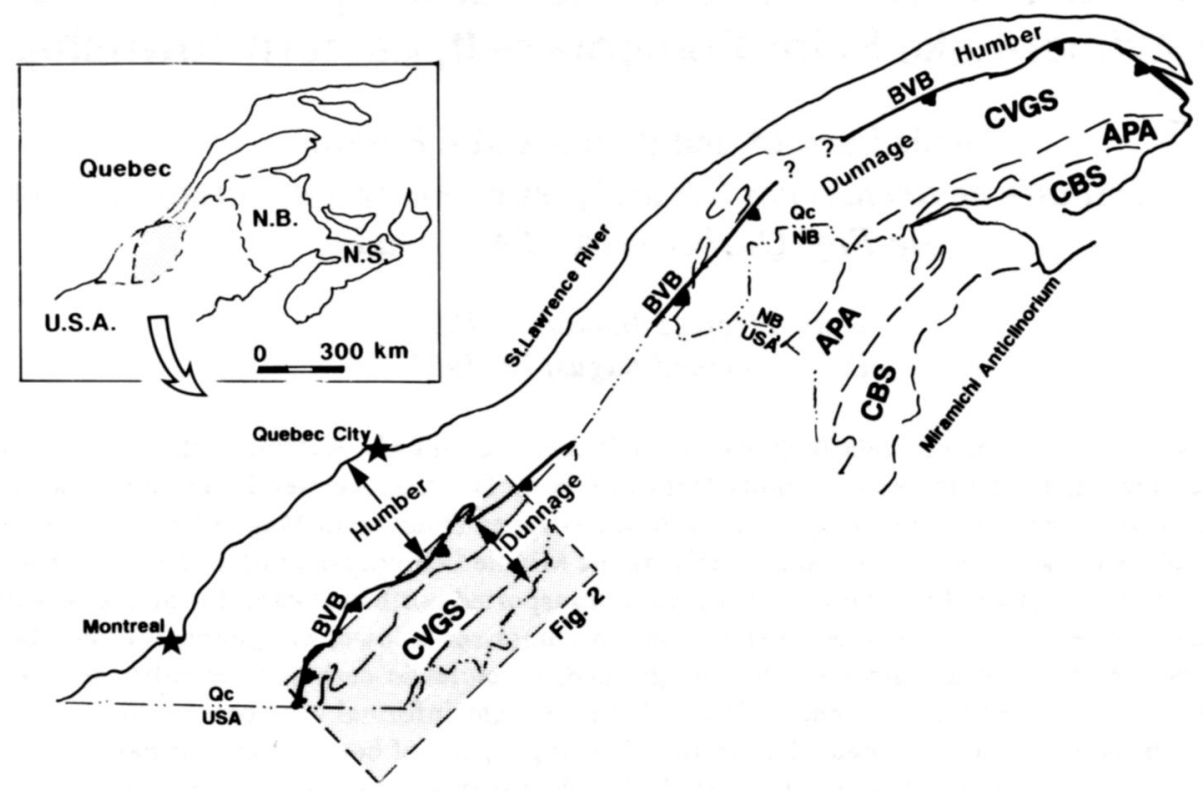

Fig. 1. Tectonostratigraphic zonation of post-Taconian rocks in Québec and New Brunswick. CVGS - Connecticut Valley-Gaspé Synclinorium; APA - Aroostook-Percé Anticlinorium; CBS - Chaleurs Bay Synclinorium; BVB - Baie Verte-Brompton line. Shaded area is location of Figure 2. Modified from Williams (1978).

graphy are relatively well understood (Bourque, 1975, 1977; Bourque and Lachambre, 1980; Malo and Bourque, in press; Bourque $e t$ al., in press). The post-Taconian succession of the Eastern Townships, situated along strike to the southwest of the Gaspé Belt (Fig. 1), has only been the subject of regional mapping and stratigraphy (St-Julien, 1970; Lavoie, 1985; Slivitzky and St-Julien, 1987; Labbe, 1991). However, the Eastern Townships succession is less complete than the Gaspé succession, since only the Silurian to Lower Devonian (assemblages 2 and 3 ) successions are recognized. Bourque $e t$ al. (in press) tentatively correlate the base of the Eastern Townships sequence with the beginning of the second major transgressive event recorded in the Gaspé Belt.

This paper documents the stratigraphy and sedimentology of part of the poorly known post-Taconian succession of the Eastern Townships. It focuses on two units, the Silurian Lac Aylmer and Lac Lambton formations, which both occur in the lower portion of the post-Taconian succession but form parts of distinct tectonic domains. The data presented relies on six composite stratigraphic sections and petrographic descriptions of more than $\mathbf{1 1 0}$ thin sections.

\section{Geological Setting}

The Eastern Townships of southern Québec are underlain by Lower and Middle Paleozoic rocks that have been deformed by two major orogenic episodes, the Taconian (Late Ordovician) and Acadian (Middle Devonian) orogenies (Slivitzky and St-Julien, 1987). As such, they are divided into two broad packages: the pre-Taconian Ordovician rock as- semblage (the St. Daniel mélange, Ascot Complex and Magog Group; Tremblay, 1992a) and the post-Taconian-pre-Acadian rock assemblage of Silurian-Devonian age (Figs. 2,3). The Silurian-Devonian rocks crop out in a number of lithotectonic units belonging to two structural domains (Figs. 2, 3): (1) a domain interpreted as autochthonous, consisting of units lying disconformably to locally unconformably on the pre-Taconian rocks; (2) an allochthonous domain, consisting of units tectonically moved northwestward along major Acadian faults. The two domains are separated by the La Guadeloupe fault, a major high-angle reverse structure (StJulien et al., 1983; Tremblay, 1992a). The amount of tectonic transport at this boundary is estimated to be at least 10 to 12 km (Labbé and St-Julien, 1989).

The Lac Memphrémagog and Cranbourne belts contain only autochthonous units (Fig. 2). In the Lake Aylmer-Lake Saint-François belt, post-Taconian successions occur in two distinct but contiguous lithotectonic units separated by the $\mathrm{La}$ Guadeloupe fault (St-Julien et al., 1983; Slivitzky and StJulien, 1987): the Lac Aylmer Formation belonging to the autochthonous domain in the Lake Aylmer syncline, and the Lake Lambton slice mostly composed of the Lac Lambton Formation and belonging to the allochthonous domain (Fig. 4). The Lake Aylmer syncline is a southwesterly plunging syncline that is upright in the northeast but shows progressive northwestward overturn towards the southwest of the area. The Lake Lambton slice exhibits a series of small tight to isoclinal folds, irregularly plunging both to the southwest and to the northeast (Lavoie, 1985). 


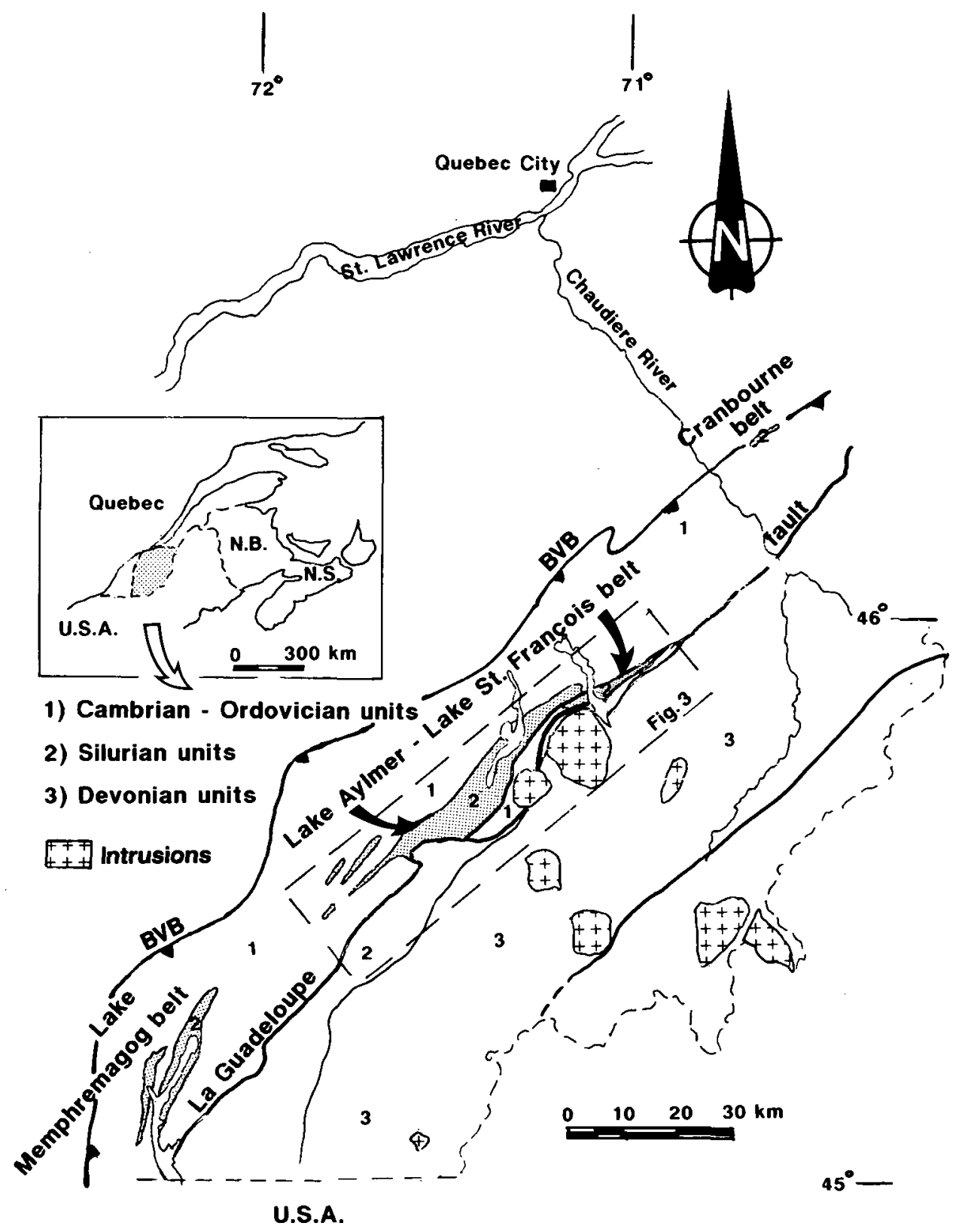

Fig. 2. Simplified geological map of southeastern Québec showing location of Silurian belts. BVB - Baie Verte-Brompton line. Location on Figure 1. Dashed lines show location of Figure 3.

\section{LithOSTRATIGRAPHY}

\section{Lac Aylmer Formation}

The term Lac Aylmer Formation was introduced by Burton (1930) to designate conglomerates and limestones unconformably overlying Ordovician rocks in the vicinity of Lake Aylmer. The term was subsequently applied to all Silurian rocks of the syncline between Lake Saint-François to the northeast and the village of Dudswell to the southwest (Fig. 3). Slivitzky and St-Julien (1987), following age assignment and nomenclature of Boucot and Drapeau (1968) and St-Julien (1970), respectively, proposed the most widely accepted stratigraphic framework for the area.
The Lac Aylmer Formation disconformably overlies the Middle to Upper Ordovician Magog Group (Fig. 3), the siliciclastic infill of a forearc basin (Cousineau, 1990) mildly deformed in the Taconian orogeny. The thickness of the Lac Aylmer Formation reaches nearly $1200 \mathrm{~m}$. The formation is made up of a dominantly siliciclastic lower part and a mixed carbonate-siliciclastic upper part. The Lac Aylmer Formation is divided into three informal members (Ay1 to Ay3; StJulien, 1970), the lower two of which correspond to the siliciclastic-dominated part (Table 1). Member Ayl mostly consists of thickly bedded (up to $3 \mathrm{~m}$ ), clast-supported conglomerates. They are composed of dominantly rounded, granule- to cobble-size clasts with, in decreasing order of abundance: rhyolitic porphyries, albite-rich granites, grano- 


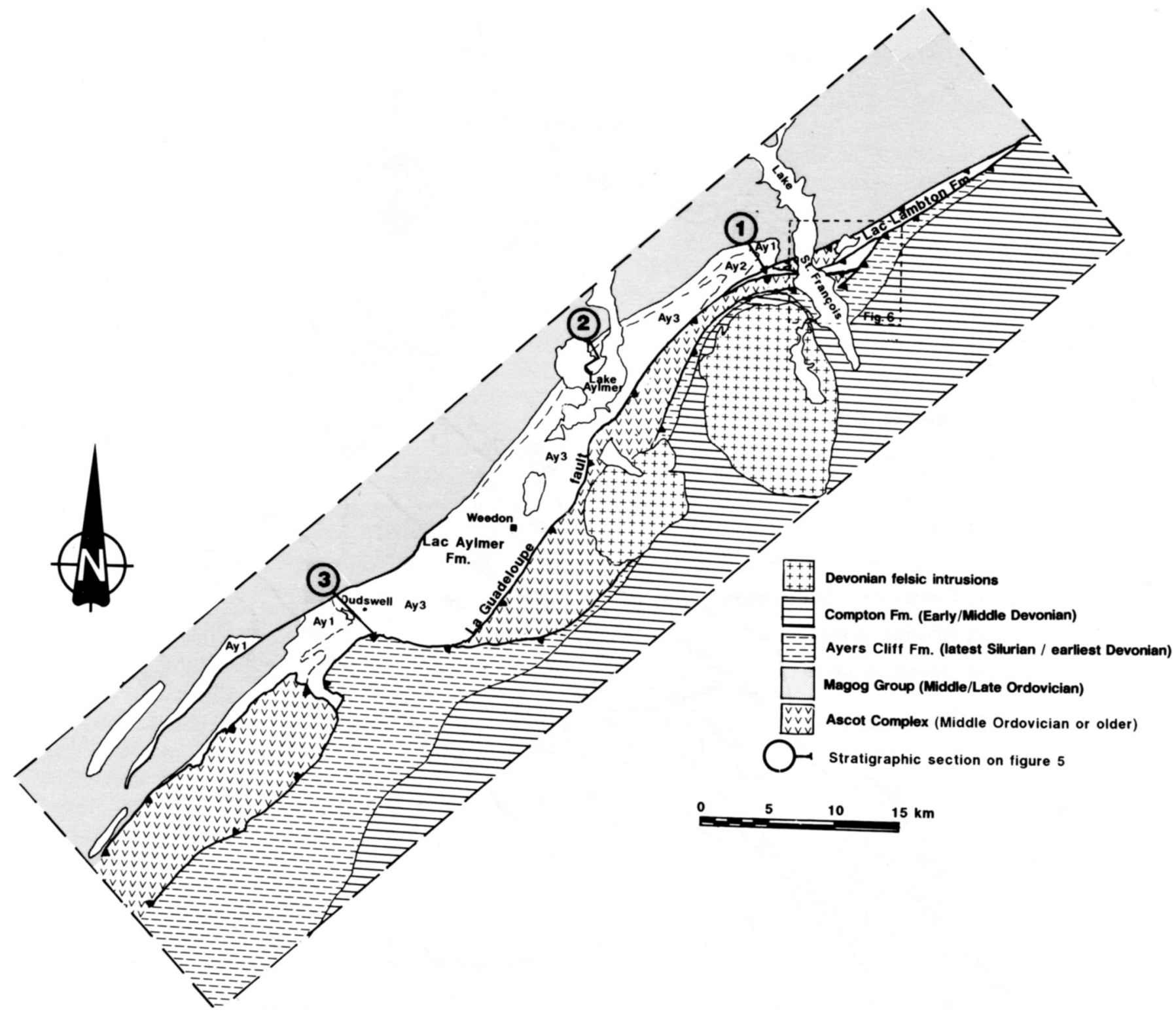

Fig. 3. Geology of the Silurian Lake Aylmer-Lake Saint-François belt including contiguous pre-Taconian rocks. Distribution of the Lac Aylmer and Lac Lambton formations are shown in white, with location of the three composite stratigraphic sections of the Lac Aylmer Formation. Ay1 to Ay3 refer to members of the Lac Aylmer Formation. Location on Figure 2. Dashed lines show location of Figure 6. Geology modified from Slivitzky and St-Julien (1987, map 2030).

phyres, chlorite-, albite- and sericite-schists, quartz and uncommon sedimentary rocks (siltstone, chert and quartzite). The fragments make up to $80 \%$ of the rock volume with the sandy matrix compositionally similar to the clasts. The conglomerates (65\%) alternate with lithic sandstones (20\%), siltstones (10\%) and shales (5\%). Member Ay2 is composed of parallel laminated and sometimes graded, medium- to coarse-grained, lithic sandstones (85-60\%) and siltstones (15-40\%). Sandstones are in planar beds ranging from 10 to $50 \mathrm{~cm}$ thick, whereas siltstones occur as centimetre to decimetre size interbeds. Member Ay3 is distinguished by silty calcilutites (60-40\%) and calcareous siltstones (40-60\%), with synsedimentary rotational and translational slide structures. Both lithologies contain sparse crinoid and coral faunas.
In the Dudswell area, at the southwestern extremity of the syncline (Figs. 3, 5), a 200 m-thick unit of very pure stromatoporoid-rich, reefoid limestone occurs. Other smaller occurrences are known to the northeast (Labbé, 1991). The southwesternmost occurrence has been recently divided into three sub-units (Hughson and Stearn, 1989): (1) a basal nodular calcareous siltstone; (2) a middle floatstone, rudstone and sedimentary breccia; and (3) an upper lime-mudstone, stromatoporoid and coral breccia and stromatoporoid framestone. The overall volume of the reefoid limestones is minor in the dominantly fine-grained succession of member Ay3.

Three composite stratigraphic cross-sections were constructed from isolated outcrops to establish the internal stratigraphy of the Lake Aylmer syncline (Figs. 3, 5). At the 


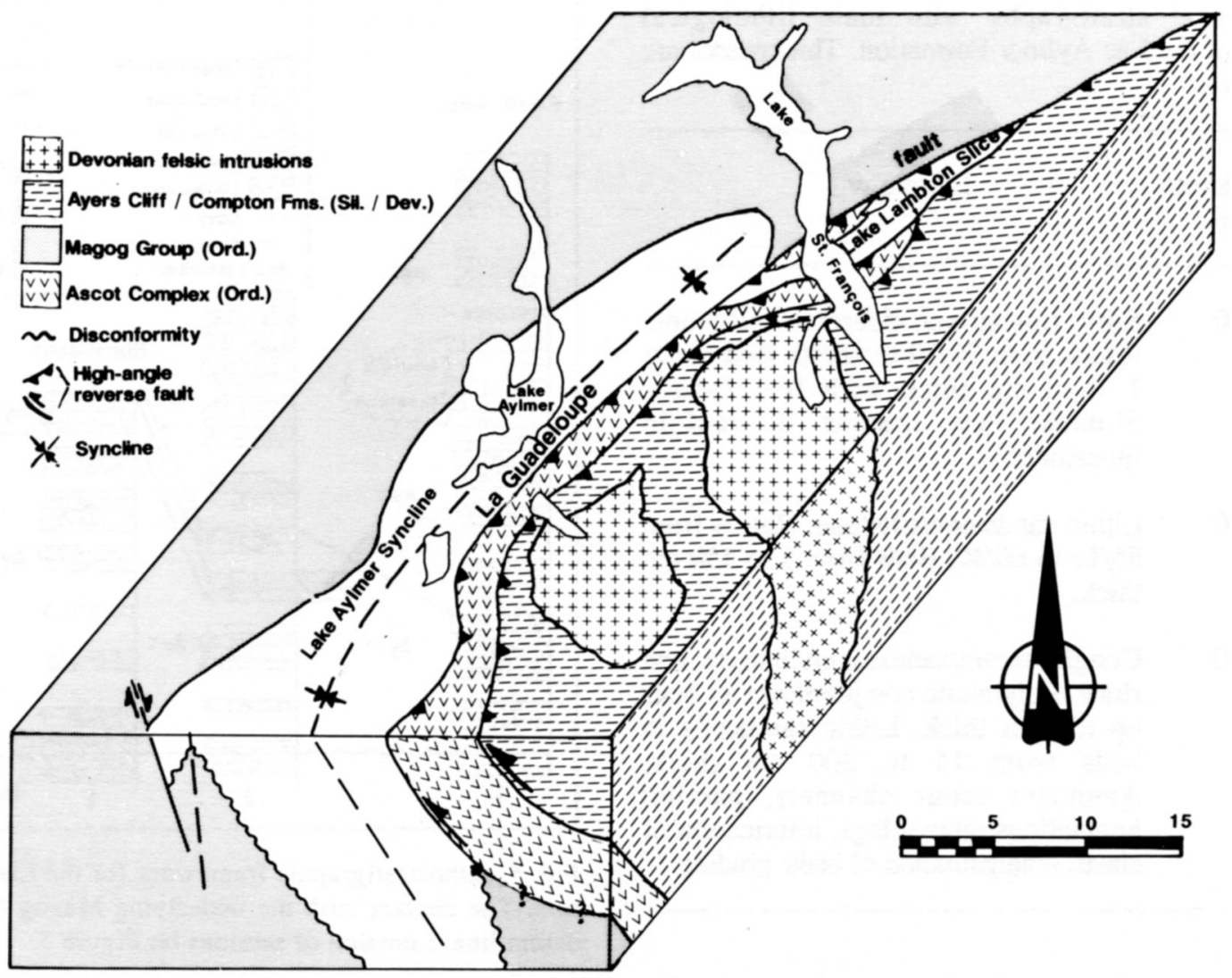

Fig. 4. Schematic block diagram illustrating the structural domains and lithotectonic units of the studied area. The Lac Aylmer and Lac Lambton formations are shown in white.

northeastern end of the syncline (Fig. 5, section 1), only members Ay1 $(660 \mathrm{~m})$ and Ay2 $(70 \mathrm{~m})$ are recognized. Farther southwest, in the vicinity of Lake Aylmer (Fig. 5, section 2), all three members are recognized. The thickness of basal member Ay1 reaches a maximum of $300 \mathrm{~m}$. Member Ay 2 is $50 \mathrm{~m}$ thick, and is overlain by a conglomeratic unit similar to the underlying member Ayl, suggesting that member Ay 2 is partially surrounded by member Ay1. Member Ay3 is well exposed on the shores of Lake Aylmer, where it reaches a maximum of $400 \mathrm{~m}$ and overlies the upper conglomeratic unit assigned to member Ayl. Finally, at the southwestern end of the syncline (Fig. 5, section 3), only members Ay1 $(240 \mathrm{~m})$ and $A y 3(850 \mathrm{~m})$ are recognized.

\section{Lac Lambton Formation}

The term Lac Lambton Formation was introduced by StJulien (1970) for the lowermost post-Taconian unit of the Saint-Francis Group (Cooke, 1937) outcropping in the vicinity of Lake Saint-François. More recently, the Lac Lambton Formation has been recognized farther southwest (Labbé, 1991). The Lake Saint-François area is structurally complex, with numerous thrusts and tectonic wedges of pre-Taconian rocks encased within the succession of the Lac Lambton Formation (Fig. 6). The pre- and lowermost post-Taconian successions belong to the herein introduced Lake Lambton slice (Figs. 4, 6). This lithotectonic unit is limited to the north by the La Guadeloupe fault and to the south by an unnamed thrust, which separates the Lac Lambton Formation from the uppermost Silurian-lowermost Devonian Ayers Cliff Formation (Slivitzky and St-Julien, 1987).

In places, the Lac Lambton Formation unconformably overlies the intensely Taconian-deformed rocks of the Middle Ordovician or older Ascot Complex, an interpreted remnant of a subduction-related volcanic pile (Tremblay et al., 1989b); elsewhere, it is in fault contact with the Middle to Upper Ordovician Magog Group. It is in turn structurally overlain by the Ayers Cliff Formation. The Lac Lambton Formation has an overall thickness of $1100 \mathrm{~m}$. The formation is composed of conglomerates, sandstones, fine-grained siliciclastics (shale and siltstone) and subordinate carbonates (dolostone and minor limestone). The succession is divided into eight informal members, A to $\mathrm{H}$ (Lavoie, 1985), whose succession and main lithologic features are summarized on Figure 7 and Table 2; their geological distribution is shown in Figure 6.

Three composite stratigraphic cross-sections were compiled from isolated outcrops to decipher lithostratigraphic relationships of the Lac Lambton Formation (Fig. 7). Member A occurs at the base of the formation throughout the area but its facies changes easterly, from a thick $(160 \mathrm{~m})$ shaly paraconglomerate in the west, to a thinner $(20 \mathrm{~m})$ matrix- 
Table 1. Internal stratigraphy with main lithological characteristics of the Lac Aylmer Formation. Thicknesses are maximum values.

\section{Member Thickness Lithology}

(m)

Ay3 $900 \quad$ Silty limestone/calcareous siltstone. Ratios from 70/30 to 60/40. Beds from 1 to $8 \mathrm{~cm}$ thick with few fossils. Slumps. Few masses of reefoid limestones.

Ay2 50 Lithic sandstone/siltstone. Ratios from $85 / 15$ to $60 / 40$. Beds from 5 to $150 \mathrm{~cm}$ thick.

Ay1 660 Conglomerate/sandstone/siltstone and shale. Polymictic conglomerate in beds up to $5 \mathrm{~m}$ thick. Lithic sandstone in beds from 15 to $200 \mathrm{~cm}$ thick. Abundant scour channels, parallel laminations, gravel lags, imbrication of clasts, amalgamation of beds, grading.

dolomitized paraconglomerate in the central sector, to an orthoquartzite $(2 \mathrm{~m})$ in the east (Fig. 7). The conglomerates are thickly bedded $(>1 \mathrm{~m})$ and composed of granule- to boulder-size, angular clasts. Clasts average $25 \%$ of rock volume and consist, in decreasing order of abundance, of rhyolitic porphyries, sericite- and chlorite-schists, albiterich granites, felsic tuffs and rhyolites. There is an eastward increase in the dolomitization of the shaly matrix of the conglomerate. This is also true for member $B$ which changes from silty calcarenites and calcilutites (B2) to silty dolomites (B1). This increase in dolomite content is clearly related to the proximity of members A and B1 to the La Guadeloupe fault in the eastern part of the Lake Lambton slice. The remainder of the stratigraphic succession is only exposed east of Lake Saint-François. It is dominated by fine-grained, mixed siliciclastic-carbonate rocks with the noticeable presence of a coarser grained member (D) containing polymictic, fine-grained conglomerates and coarse lithic sandstones. The conglomerates are crudely bedded and clast-supported. They are composed of granule- to pebble-sized, subrounded to subangular clasts. The fragments are mostly composed of quartz with subordinate rhyolitic porphyries, plagioclases, $\mathrm{K}$-feldspars, albite-rich granites and uncommon fine-grained sandstones. The matrix (average $30 \%$ ) consists of fine silts and shales, the latter showing diverse degrees of recrystallization to microspar. The conglomerates and compositionally similar sandstones contain sparse marine fossils in which few brachiopods, crinoids and rugose corals are found.

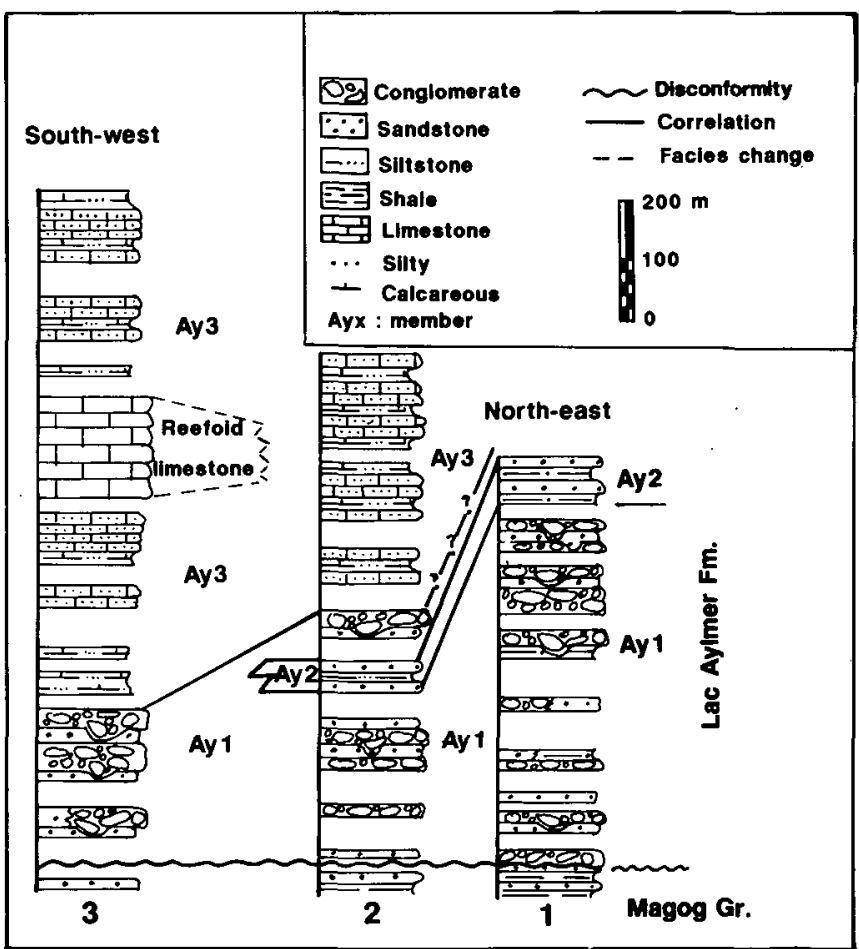

Fig. 5. Lithostratigraphic framework for the Lac Aylmer Formation. The contact with the underlying Magog Group is used as datum line. Location of sections on Figure 3.

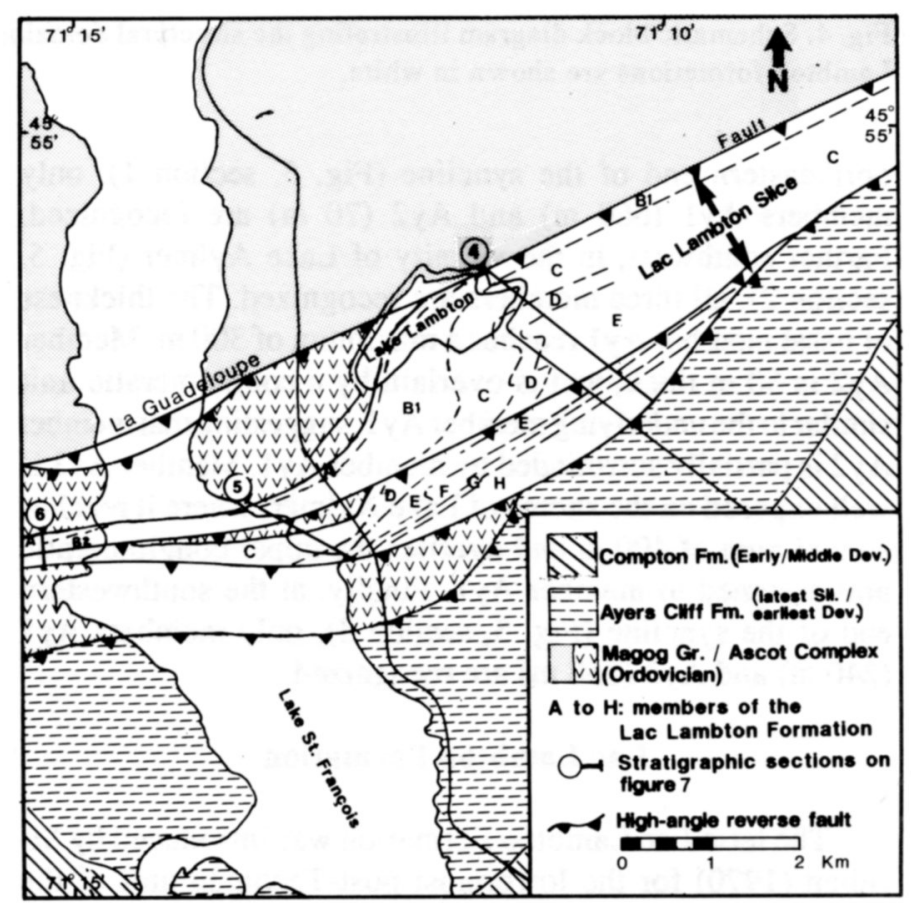

Fig. 6. Geology of the Lake Lambton slice and location of the three composite stratigraphic sections of the Lac Lambton Formation. The Lac Lambton Formation is shown in white. Location of the area is on Figure 3. Geology modified from St-Julien (1970, map 1705). 


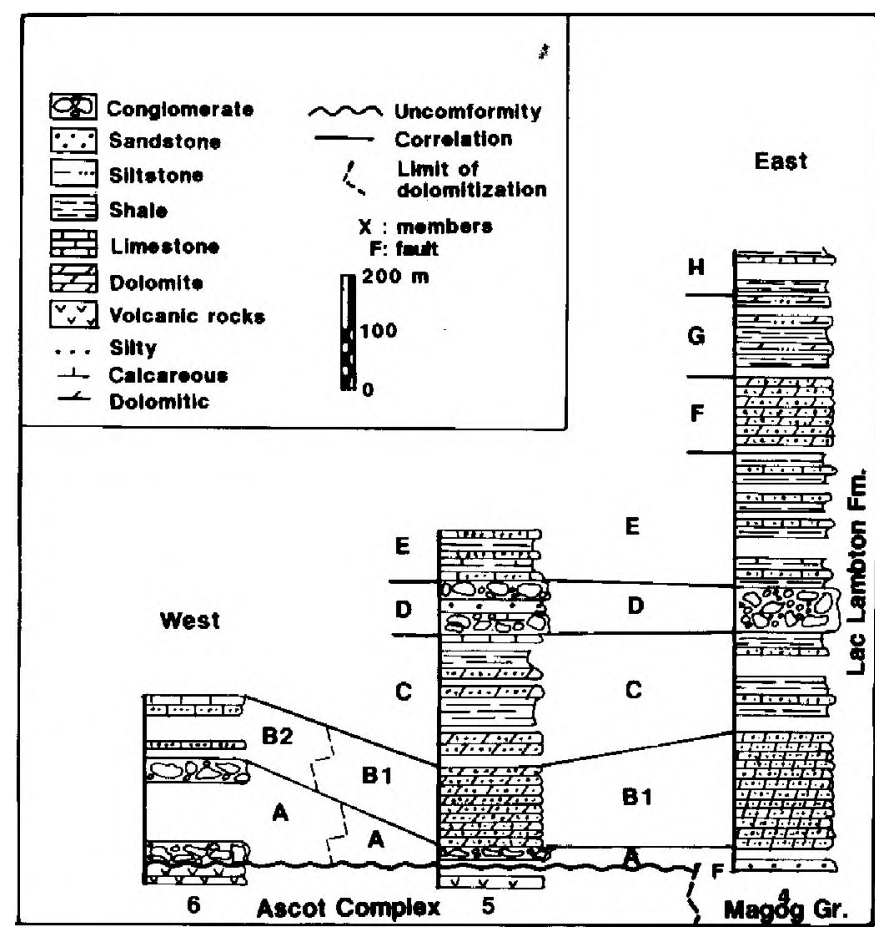

Fig. 7. Lithostratigraphic framework for the Lac Lambton Formation. The contact with the underlying Ascot Complex is used as datum line. Location of sections on Figure 6.

\section{Biostratigraphy}

The age of the Lac Aylmer and Lac Lambton formations is poorly constrained. The Lac Aylmer Formation is almost devoid of fossils, but the reefoid limestone of its upper member has yielded brachiopods dated as Pridolian or Late Silurian (Boucot and Drapeau, 1968) and stromatoporoids that relate it to the West Point Formation (Gaspe Belt) of Pridolian age (Hughson and Stearn, 1989). Although marine fossils are scattered throughout the Lac Lambton Formation, poor preservation and the small number of useful species preclude biostratigraphic studies. Only member $F$ is dated with reliability as Pridolian, based on brachiopods (Boucot and Drapeau, 1968).

\section{Sedimentology}

This study focuses on the various conglomeratic members of the Lac Aylmer and Lac Lambton formations. The reasons are: (1) conglomerates occur at the bottom of both units where they disconformably overlie the Magog Group (Lac Aylmer Formation) or unconformably overlie the Ascot Complex (Lac Lambton Formation); as such, (2) they provide critical informations on the nature of the initial infill in the post-Taconian successor basin; and (3) field exposures are commonly much better than those of the other members. The descriptions of the conglomerates are based on field descriptions and counts of clasts both in the field and under the microscope (30 thin sections).
Table 2. Internal stratigraphy with main lithological characteristics of the Lac Lambton Formation. Thicknesses are maximum values.

\begin{tabular}{cc} 
Member Thickness & Lithology \\
$(\mathrm{m})$ & \\
\hline
\end{tabular}

H $\quad 100 \quad$ Shale with minor calcilutite. Beds from 15 to $30 \mathrm{~cm}$ thick. Slumps.

G $\quad 137 \quad$ Dolomitic siltstone/shale. Ratios from $85 / 15$ to $40 / 60$. Beds from 1 to $18 \mathrm{~cm}$ thick. Parallel laminations and slumps.

F $\quad 134 \quad$ Silty dolostone, fossiliferous. Beds from 8 to $25 \mathrm{~cm}$ thick.

E $\quad 175 \quad$ Shale/calcilutite. Ratios from $99 / 1$ to $80 / 20$. Beds from 1 to $100 \mathrm{~cm}$ thick. Slumps.

D $\quad 85 \quad$ Calcareous sandstone and conglomerate. Beds from 5 to $45 \mathrm{~cm}$ thick. Fossiliferous.

C $200 \quad$ Shale/dolostone or limestone. Ratios from $90 / 10$ to 60/40. Beds from 1 to 30 cm thick. Slumps.

B $\quad 150$

Silty dolostone or limestone with lenses of conglomerate at the bottom. Fossiliferous. Cross-bedded and parallel laminations. Beds from 3 to $25 \mathrm{~cm}$ thick.

A $\quad 160 \quad$ Conglomerate in thick beds and lenses. Thin bedded orthoquartzite.

\section{Source of the clasts}

Clast composition is fairly similar for both formations (Table 3). It suggests a source dominated by felsic intrusions (rhyolitic porphyries, granophyres and albite-rich granites), felsic volcanics and meta-volcanics (felsic tuffs, rhyolites, sericite- and albite-schists), with a subordinate sedimentary and mafic meta-volcanic (chlorite-schists) component.

In the Lake Lambton slice, field exposures show that the Lac Lambton Formation unconformably overlies the Middle Ordovician or older Ascot Complex (Fig. 6). Stratigraphic relationships between the Lac Lambton Formation and the Magog Group are unknown. At the northeastern tip of the Lake Aylmer syncline, the basal Lac Aylmer conglomerate is found disconformably overlying the siliciclastic Magog Group. On the eastern flank of the Lake Aylmer syncline, the Ascot Complex is everywhere tectonically emplaced over the Lac Aylmer Formation (Figs. 3, 4).

Field and petrographic studies by Labbé and St-Julien 
Table 3. Comparisons of composition and sedimentological characteristics of the three conglomerate members of Lac Lambton (members A and D) and Lac Aylmer (member Ay1) formations.

\begin{tabular}{|c|c|c|c|}
\hline & \multicolumn{2}{|c|}{$\begin{array}{l}\text { Lac Lambton } \\
\text { Formation }\end{array}$} & \multirow{2}{*}{$\begin{array}{l}\text { Lac Aylmer } \\
\text { Formation } \\
\text { Member Ay1 }\end{array}$} \\
\hline & Member A & Member D & \\
\hline $\begin{array}{l}\text { Clast types } \\
(\mathrm{d}>2 \mathrm{~mm})\end{array}$ & $\begin{array}{ll}\text { Porphyry } & 50 \% \\
\text { Schist } & 30 \% \\
\text { Granite } & 10 \% \\
\text { Tuff } & 10 \% \\
\text { Rhyolite } & <1 \%\end{array}$ & $\begin{array}{ll}\text { Quartz } & 40 \% \\
\text { Porphyry } & 35 \% \\
\text { Feldspar } & 15 \% \\
\text { Granite } & 10 \% \\
\text { Sandstone } & <1 \%\end{array}$ & $\begin{array}{lr}\text { Porphyry } & 40 \% \\
\text { Granites } & 30 \% \\
\text { Granophy. } & 10 \% \\
\text { Schist } & 10 \% \\
\text { Quartz } & 5 \% \\
\text { Sediments } & 5 \%\end{array}$ \\
\hline Matrix (\%) & $\begin{array}{l}20 \text { to } 80 \% \\
\text { Dolomite to } \\
\text { sandstone, both } \\
\text { shaly }\end{array}$ & $\begin{array}{l}10 \text { to } 50 \% \\
\text { Clay/calcite }\end{array}$ & $\begin{array}{l}10 \text { to } 50 \% \\
\text { Lithic sandstone }\end{array}$ \\
\hline $\begin{array}{l}\text { Clast } \\
\text { roundness }\end{array}$ & $\begin{array}{l}\text { Angular to } \\
\text { subangular }\end{array}$ & $\begin{array}{l}\text { Subrounded to } \\
\text { subangular }\end{array}$ & Rounded \\
\hline Clast size & $2 \mathrm{~mm}$ to $150 \mathrm{~cm}$ & $2 \mathrm{~mm}$ to $5 \mathrm{~cm}$ & $2 \mathrm{~mm}$ to $45 \mathrm{~cm}$ \\
\hline $\begin{array}{l}\text { Sedimentary } \\
\text { structures } \\
\text { and bedding } \\
\text { type }\end{array}$ & $\begin{array}{l}\text { Lenses to } \\
\text { massive beds }\end{array}$ & $\begin{array}{l}\text { Beds and lenses } \\
\text { Grading and } \\
\text { scours }\end{array}$ & $\begin{array}{l}\text { Channels, parallel } \\
\text { laminations gravel } \\
\text { lags, imbrication, } \\
\text { grading } \\
\text { Bed amalgamated }\end{array}$ \\
\hline Other points & $\begin{array}{l}\text { Interlayered with } \\
\text { mbr. B (bioclastic) }\end{array}$ & $\begin{array}{l}\text { Support open } \\
\text { marine fauna }\end{array}$ & $\begin{array}{l}\text { Interlayered with } \\
\text { fine-grained } \\
\text { sediments } \\
\text { Devoid of fossils }\end{array}$ \\
\hline
\end{tabular}

(1989) and Labbé (1991) in the Weedon area to the southwest (Fig. 3), have shown that the Lac Lambton Formation unconformably overlies various units of the Ascot Complex, whereas the Lac Aylmer Formation disconformably overlies the fineto coarse-grained siliciclastics of the Magog Group. Clasts in conglomerates correlated with Ay1 (Lac Aylmer Formation) and $A$ (Lac Lambton Formation) members are dominated by felsic volcanic änd intrusive rocks and do not show any significant variation from those previously discussed. These authors have shown that the lithologies of the clasts are similar to those of the nearby Ascot Complex. This observation, coupled with ours, suggests that the Magog Group was probably not a major topographic high in early post-Taconian time; all field and petrographic work suggests a single volcanic and plutonic source, the Ascot Complex.

Depositionăl envirónments of conglomerates Members Ay1 and Ay2 (Lac Aylmer Formation)

Member Ayl of the Lac Aylmer Formation is a thick succession of interlayered coarse- to fine-grained siliciclastics. The conglomerates are clast-supported and commonly unsorted (Fig. 8A). Sedimentary structures include parallel laminae, imbrication of clasts, centimetre- to metre-sized channels, grading, and gravel lags preserved as basal layers at the bottom of several beds. Amalgamation of beds is discernible where marked by abrupt changes in clast size (Fig. 8A). These conglomerates would be classified as facies $\mathrm{Gm}$ using Miall's (1978) facies code. The associated lithic sandstones are of the same composition as the conglomerates. They are horizontally stratified (facies Sh; Miall, 1978) with some parallel laminae and centimetre-sized discontinuous pebbly layers. Sandstone beds commonly overlie conglomerates; they are in turn either conformably overlain by finer-grained sediment (Fig. 8B) or show scoured upper contacts where overlain by conglomerates. Finally, siltstone and shale are minor but ubiquitous components, generally associated with the sandstone-rich part of the succession (Fig. 8B). They occur as graded and laminated couplets overlying sandstone beds.

The thick Ayl association of conglomerates and sand- 

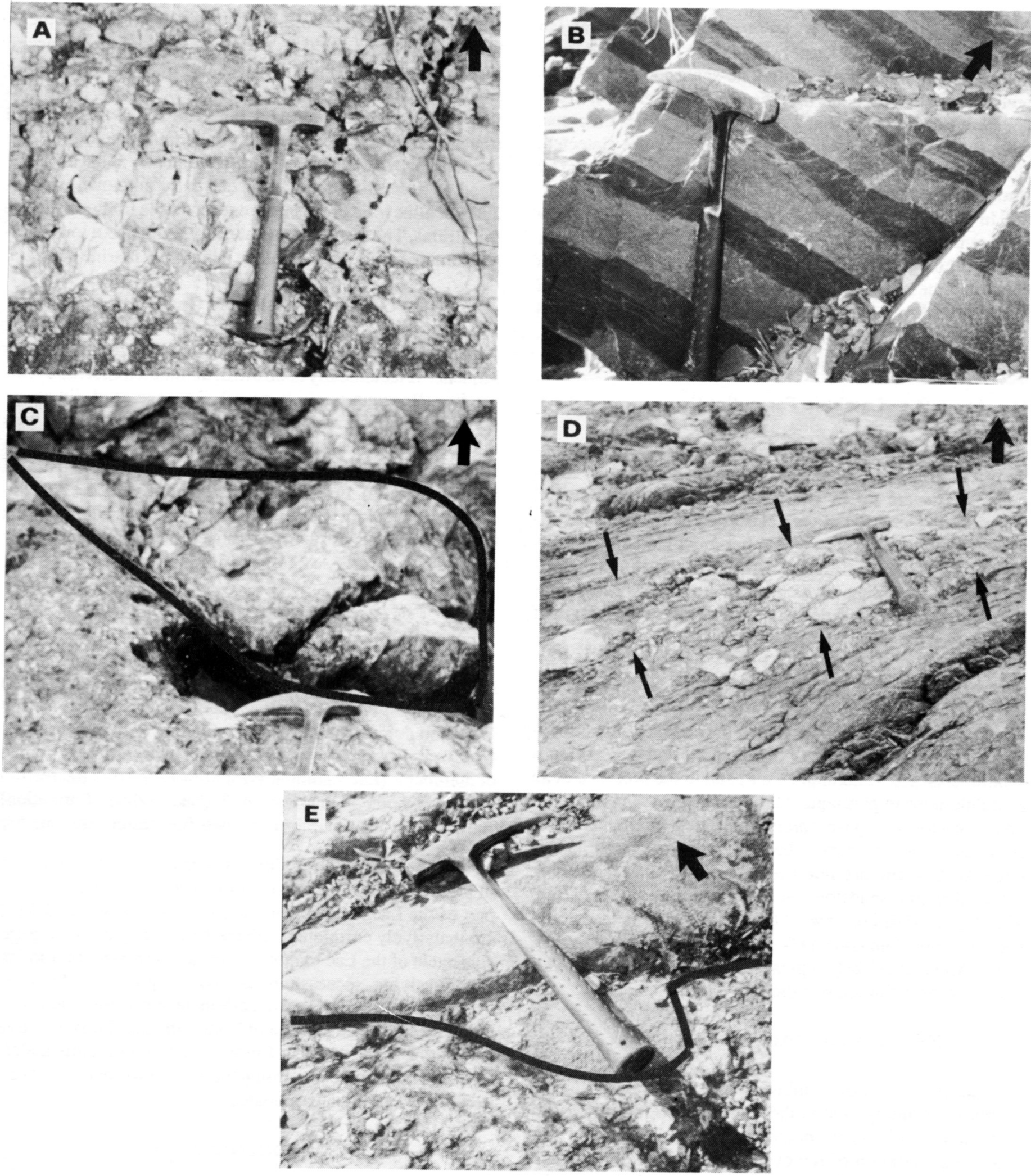

Fig. 8. Field photographs of conglomerates. (A) Amalgamated bed of rounded unsorted clasts in a clast-supported conglomerate (facies $\mathrm{Gm})$. Clasts are mostly rhyolites and porphyries. Stratigraphic top is indicated by the arrow. Member Ayl of Lac Aylmer Formation, section 2 (Figs. 3, 5). (B) Planar bedded sandstones (facies Sh) interlayered with darker shaded siltstones-shales couplets. Member Ayl of Lac Aylmer Formation, section 1 (Figs. 3, 5). (C) Large angular clasts in an unsorted and matrix-supported conglomerate (facies $\mathrm{Gms}$ ). The boulder-sized clast (outline in black) is sericite-schist. Stratigraphic top is indicated by the arrow. Member A of Lac Lambton Formation, section 5 (Figs. 6,7). (D) Decimetre-sized lense (outline by small arrows) of member A conglomerate interlayered with silty dolomite of member B1. Stratigraphic top is indicated by the large arrow. Lac Lambton Formation, section 5 (Figs. 6, 7). (E) Scour (base outline in black) into fine-grained, clast-supported conglomerate; the structure is filled by lithic sandstone. Stratigraphic top is indicated by arrow. Member D of Lac Lambton Formation, section 5 (Figs. 6, 7). 
stones is interpreted to represent a proximal alluvial fan environment (Rust and Koster, 1984); the relatively thinner association of sandstone and siltstone-shale couplets is interpreted as ephemeral pond fills resulting from channel abandonment (Rust and Koster, 1984). In some larger outcrops, both fining- and coarsening-upward cycles are detected. However, a comprehensive study of cyclicity is precluded by restricted field occurrences.

In the vicinity of Lake Aylmer, field relationships show that member Ay2 is enclosed within member Ayl. Member Ay2 is lithologically similar to member Ay1, the absence of conglomerate in Ay 2 being the only difference. Member Ay 2 is interpreted as a more distal facies of the alluvial fan, that was out of reach of gravelly sedimentation (Rust and Koster, 1984).

\section{Member A (Lac Lambton Formation)}

Member A conglomerates of the Lac Lambton Formation are matrix-supported and lack internal sedimentary structures. Clasts are up to $150 \mathrm{~cm}$ in diameter, angular and unsorted (Fig. 8C). These are classified as facies $\mathrm{Gms}$, following Miall's (1978) code. Member A conglomerates interdigitate with the fossiliferous (trilobites, brachiopods, crinoids) silty dolomites of member B (Fig. 8D). These conglomerates are possible debris flow deposits at the margin of the post-Taconian successor basin.

\section{Member D (Lac Lambton Formation)}

Conglomerates of member $\mathrm{D}$ of the Lac Lambton Formation differ from the other conglomerates in possessing a smaller clast size (maximum $5 \mathrm{~cm}$ ) and in the presence of an autochthonous to para-autochthonous marine fauna (brachiopods, crinoids, rugose corals) dispersed throughout. The conglomerates are crudely bedded, clast-supported, sometimes graded, and are interbedded with parallel laminated, lithic calcareous sandstone. Scours are locally observed (Fig. 8E). A general fining-upward trend is detected as sandstones become more abundant and finer-grained upsection (Lavoie, 1985). Member $D$ likely represents marine sands and gravels deposited on a siliciclastic shelf (Walker, 1984).

\section{Paleoenvironment Evolution}

The succession of members $A$ to $\mathrm{H}$ in the Lac Lambton Formation is interpreted as the result of three transgressiveregressive (T-R) cycles (members A-D; D-F; G-H; Lavoie, 1985). The duration of the cycles is unknown. The lack of biostratigraphic data for most of the unit precludes correlation of cyclicity with post-Taconian eustatic events. Moreover, the regressive part of the second T-R cycle (D-F), which ended in the sedimentation of carbonates of Pridolian age (member F), is time correlative with the peak of a major tectonically controlled shallowing event (Salinic disturbance) in the Gaspé Belt (Bourque et al., in press).

Lack of biostratigraphic data is also a major problem with the Lac Aylmer Formation. The transition from members Ay1 to Ay2 could be seen as a major fining-upward sequence resulting either from: (1) decreasing relief of the source area, (2) change in the drainage pattern or, (3) migration of the proximal alluvial fan. The coarsening-upward transition at the top of member Ay2 could be interpreted in the same way, with increasing (tectonically induced ?) instead of decreasing relief. It is currently unknown whether auto- or allocyclic processes are responsible for the observed transitions. The overlying member Ay 3 supports a low diversity fauna of crinoids and corals; it is clearly marine in origin.

\section{Comparison with the Gaspé Belt}

In the Gaspe Belt, the low order cyclicity for the Silurian sequence is tectonically controlled; undoubted eustatic events are few (Bourque et al., in press). Bourque et al. (in press) correlate the Lac Lambton and Lac Aylmer formations with the lower part of the succession developed as the result of the second post-Taconian sea-level rise (uppermost part of Chaleurs Group). From these considerations and the Appalachian setting of the Eastern Township succession, it seems likely that sea-level fluctuations were mostly controlled by tectonism.

\section{Stratigraphic Correlation}

The lithostratigraphic successions of the Lac Aylmer and Lac Lambton formations are sufficiently similar to propose lithostratigraphic correlations. Both successions overlie Taconian deformed units, thus indicating they are post-Late Ordovician in age. Pridolian ages obtained from the dolomite of member F (Lac Lambton Formation) and from the reefoid limestone body of member Ay3 (Lac Aylmer Formation) show that at least parts of the two formations are roughly coeval.

The proposed correlation between the two units is shown in Figure 9. The siliciclastic alluvial sediments of the lower part of the Lac Aylmer Formation (members Ay1 and Ay2) are tentatively correlated with the first transgressive-regressive cycle of the Lac Lambton Formation (members A to D). The overlying successions are both represented by finegrained, mixed siliciclastic-carbonate sediments, with one common carbonate horizon of Pridolian age. If this tentative correlation is accepted, it follows that the two units underwent dissimilar paleoenvironmental evolution before deposition of the Pridolian carbonates.

\section{Paleogeography}

The paleogeographic model for the area must be in accord with the available tectonostratigraphic constraints. The Lac Aylmer Formation disconformably overlies the Middle to Upper Ordovician forearc sediments of the Magog Group. The contact between the Lac Aylmer Formation and Middle Ordovician or older volcanic arc Ascot Complex is tectonic. However, although the contact between the Magog 


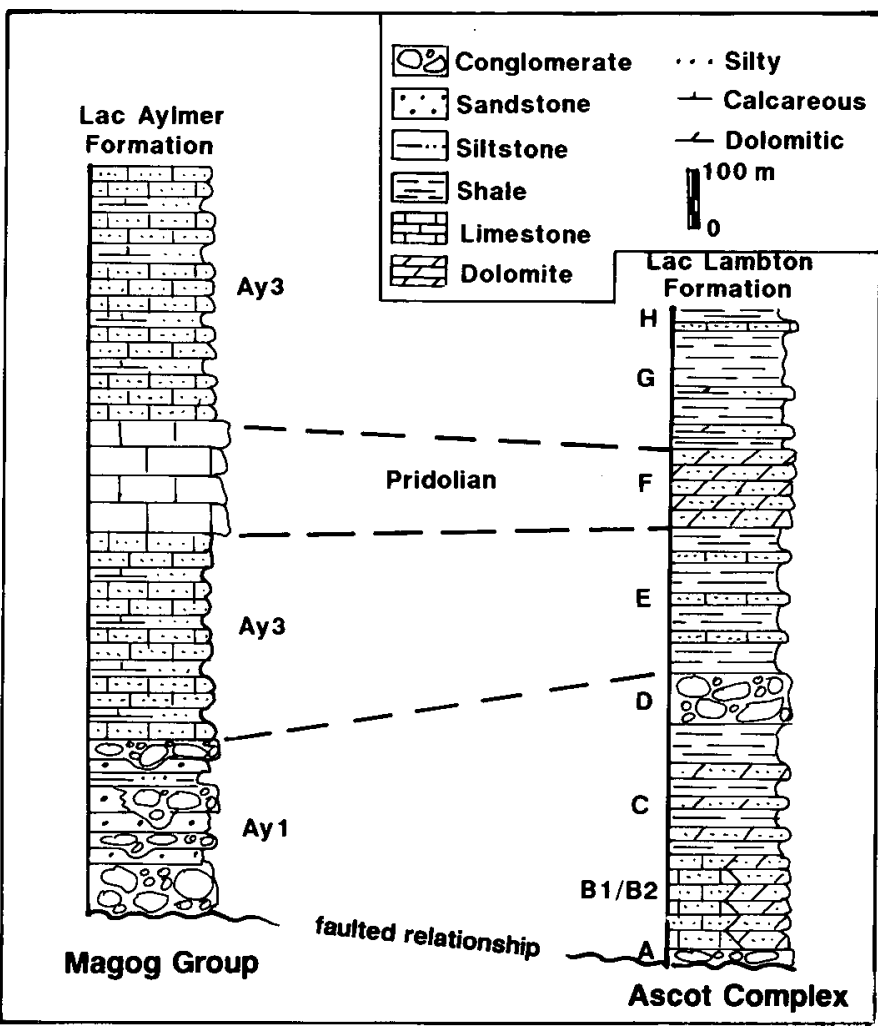

Fig. 9. Correlation for the Lac Aylmer and Lac Lambton formations. Succession for the Lac Aylmer Formation is from the Dudswell area (Figs. 3, 5); succession for the Lac Lambton Formation is summarized from the area east of Lake Saint-François (Figs. 6, 7). Datum line is the Pridolian dated reefoid limestone of member Ay3 (Lac Aylmer Formation) and silty dolomite of member F (Lac Lambton Formation).

Group and the slightly older Ascot Complex is commonly faulted (Labbé and St-Julien, 1989; Cousineau, 1990), an unconformable relationship is also locally observed (Tremblay, 1992a).

The Lac Lambton Formation unconformably overlies the Ascot Complex in both the Lake Saint-François (Fig. 6) and Weedon areas (Labbé, 1991). The contact between the Lac Lambton Formation and the Magog Group is faulted (Fig. 6).

From the above considerations, it is obvious that the $\mathrm{La}$ Guadeloupe fault and subsidiaries played an important role in the tectonostratigraphic history of the area. Structural studies have shown that the La Guadeloupe fault is an Acadian northwestward-directed, high-angle reverse structure along which post-Taconian rocks as well as pre-Taconian slivers (Ascot Complex) were transported over rocks of the former Dunnage Zone (Tremblay et al., 1989a; Labbé and St-Julien, 1989; Tremblay, 1992a). The anomalous young over old rocks geometry is interpreted as the product of pre-existing movement along this fault plane (normal or strike-slip), or may result from a fault plane cutting through a higher angle angular unconformity (Tremblay, 1992a). A deep seismic profile recognized the La Guadeloupe fault as a low-angle, southeast-dipping reflector extending along the Connecticut Valley-Gaspé Synclinorium (St-Julien et al., 1983). As suggested by Tremblay (1992a), this makes the second hypothe- sis more probable. A multiple-stage history of the La Guadeloupe fault is not ruled out, but structural evidence is lacking.

The correlation between the Lac Aylmer and Lac Lambton formations (Fig. 9) can be explained in two ways. The first model postulates a single sedimentary basin. Paleoenvironmental differences at the base of the two successions would then be explained by position of the respective sedimentation areas relative to emergent post-Taconian terranes. The area of Lac Aylmer Formation sedimentation is interpreted as more proximal to positive elements (Ascot Complex) than the depositional site of the Lac Lambton Formation, which was more rapidly subjected to a post-Taconian (tectonic or eustatic ?) relative sea-level rise (Lavoie, 1985). However, since field relationships show that the Lac Aylmer Formation was deposited on forearc sediments (Magog Group; Fig. 3) and the Lac Lambton Formation unconformably overlies the volcanic arc (Ascot Complex; Fig. 6), it follows that the lateral facies variation hypothesis is a highly questionable scenario.

The second model implies two distinct sedimentary basins separated by the Ascot high (Fig. 10). The Lac Lambton basin was located on the seaward side and in contact with the positive element. It was affected by a (tectonic or eustatic ?) relative sea-level rise that followed the Ascot accretion. The Lac Aylmer basin was the site of fluvial sedimentation occurring on the mildly deformed, low relief, forearc sediments of the Magog Group. Finally, in Late Silurian time, the sea progressively invaded the Lac Aylmer sedimentary basin.

\section{Conclusions}

Two distinct lithostratigraphic successions constitute the Silurian Lake Aylmer-Lake Saint-François belt in the Eastern Townships of the Québec Appalachians. One is the Lac Aylmer Formation, an apparently autochthonous succession lying with disconformity over the pre-Taconian forearc sediments of the Magog Group. It is a thick, coarse- to finegrained, siliciclastic succession of probable fluvial origin, overlain by an impure, fine-grained carbonate succession containing a low diversity and rare marine fauna and local reefoid limestone bodies. The other is the Lac Lambion Formation, an allochthonous succession transported northwestward along the Acadian La Guadeloupe fault. It is a heterogenous succession of coarse- to mostly fine-grained siliciclastics and carbonates, in which all but a thin lowermost unit contain marine fauna. Field and petrographic analysis of the conglomerates of both formations has revealed a similar clast source, probably the Middle Ordovician or older volcanic arc system of the Ascot Complex. The study also documents major differences in depositional environments of the conglomerates in the two successions. Paleogeographically, it is concluded that prior to Late Silurian time, the various sedimentary units were deposited within distinct basins separated by the Ascot Complex.

The basal contact between pre- and post-Taconian units is either a disconformity where the latter overly the Middle to 


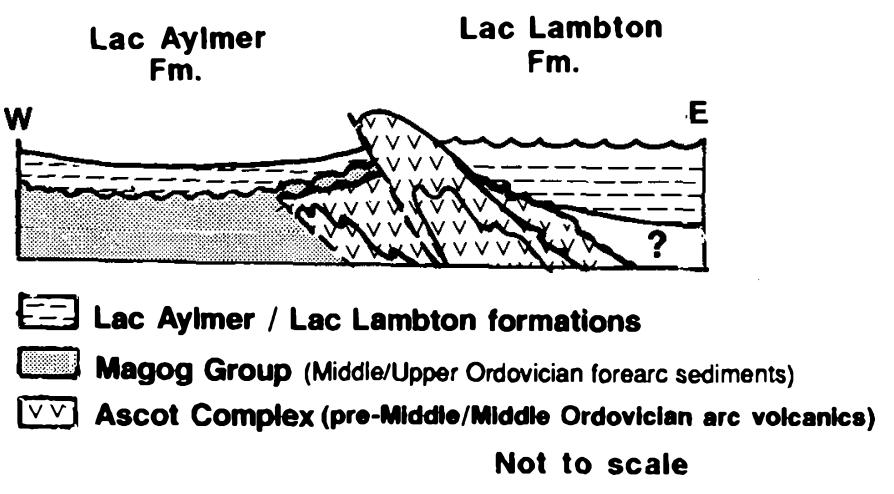

Fig. 10. Simplified paleogeographical model proposed for the Lake Aylmer-Lake Saint-François Silurian belt in pre-Late Silurian time. Modified from Tremblay (1989, Fig. 2).

Upper Ordovician Magog Group, or a high angle unconformity where post-Taconian units overlie the Middle Ordovician or older Ascot Complex. This is explained by the fact that the Magog Group was only mildly affected by the Taconian orogeny, the peak of deformation in that area having occurred during the Acadian orogeny (Cousineau, 1988; Tremblay, 1992a). Evidence of strong Taconian deformation within the Dunnage Zone is only recorded in the Lower to Middle Ordovician St. Daniel mélange (St-Julien and Hubert, 1975) and Middle Ordovician or older Ascot Complex. The age of the lower part of the post-Taconian succession and thus of the disconformity/unconformity, is unknown and could range anywhere from Late Ordovician to early Late Silurian.

In the post-Taconian-pre-Acadian time span, effects of a minor orogenic event, referred to as the Salinic disturbance, (Boucot, 1962) are observed at many places in the northern Appalachians, from Late Silurian in the Gaspé Basin (Bourque et al., in press; Malo and Bourque, in press) to Early Devonian in Vermont (Berry and Boucot, 1970). In the Gaspé peninsula, the Salinic disturbance was mainly expressed by block faulting during Ludlovian-Pridolian times, thus creating a number of smaller secondary basins within the broader Gaspe Basin (Bourque, 1990) and heralding the Acadian orogeny. The sub-Lac Aylmer disconformity and sub-Lac Lambton unconformity, as well as the existence of two distinct sub-basins formed prior to the Late Silurian, may be related to this Salinic event. In the Gaspé, distribution of Upper Silurian reef facies appears to have been controlled by block faulting (Bourque, 1990). Similar block faulting is suggested by Hughson and Stearn (1987) for explaining the distribution of the reef bodies of the Ay3 member of the Lac Aylmer Formation in the Eastern Townships. However, no evidence of major and regional pre-Late Silurian normal faulting is known in the Eastern Townships(Tremblay, 1992a). Obviously, in the absence of better dating, these conclusions remain speculative.

\section{Acknowledgements}

Financial support through a Québec Ministry of Education (Fonds pour la formation de chercheurs et l'aide à la recherche) grant (EQ-1005) to P.-A. Bourque and a postgraduate Natural Sciences and Engineering Research Council of Canada scholarship to D. Lavoie, is acknowledged. Reviews of the manuscript by C.W. Stearn, J.W.F. Waldron and an anonymous reviewer helped to clarify our ideas. Their suggestions and comments are greatly appreciated.

BerRY, W.B.N. and Boucot, A.J. 1970. Correlation of the North American silurian rocks. Geological Society of America, Special Paper 102, 289 p.

Boucot, A.J. 1962. Appalachian Siluro-Devonian. In Some aspects of the $\mathrm{V}$ ariscan fold belt. Edited by K. Coe. Manchester University Press, Manchester, England, pp. 155-163.

Boucot, A.J. and DrapeaU, G. 1968. Roches siluro-dévoniennes du lac Memphrémagog et roches équivalentes dans les Cantons de l'Est. Ministère des Richesses Naturelles, Québec. ES-1, 46 p.

BourQUe, P.-A. 1975. Lithostratigraphic framework and unified nomenclature for Silurian and Basal Devonian rocks in Eastern Gaspé Peninsula, Québec. Canadian Journal of Earth Sciences, 12, pp. 858-872.

1977. Le Silurien et le Dévonien basal du Nord-est de la Gaspésie. Ministère des Richesses Naturelles, Québec, ES29, 232 p.

1990. La pulsation salinienne en Gaspésie-Témiscouata: nature de la déformation et contrôle de la distribution des récifs de la fin Silurien - début Dévonien. In 1990 QuébecMaine-New Brunswick Appalachian Workshop. Edited by M. Malo, D. Lavoie and D. Kirkwood. Geological Survey of Canada, Open File No. 2235, pp. 25-26.

Bourque, P.-A. and Lachambre, G. 1980. Le Silurien et le Dévonien basal du sud de la Gaspésie. Ministère de l'Energie et des Ressources, Québec, ES-30, 122 p.

Bourque, P.-A., Brisebois, D., and Malo, M. In press. Middle Paleozoic rocks of Québec and adjacent New-Brunswick. In The Appalachian - Caledonian Region: Canada and Greenland. Edited by H. Williams. Decade of North American Geology, Volume F1.

Burton, F.R. 1930. Les environs du lac Aylmer, Cantons de l'Est. Ministère des Mines, Québec, Annual Report, Part D, pp. 115-165.

Cooke, H.C. 1937. Région de Thetford, de Disraëli et la moitié est de Warwick (Québec). Geological Survey of Canada, Memoir 211.

Cousineau, P.A. 1988. Paléogéographie et évolution tectonique d'une partie de la zone de Dunnage à l'est de la rivière Chaudière. Ph.D. thesis, Laval University, Quebec City, 285 p.

1990. Le Groupe de Caldwell et le domaine océanique entre Saint-Joseph-de-Beauce et Sainte-Sabine. Ministère de l'Énergie et des Ressources, Québec, MM 87-02, 165 p.

Huohson, R.C. and Stearn, C.W. 1987. Reversed craton-tobasin trend in the Silurian of the Quebec Appalachians. 
Geological Society of America, Annual meeting, Programs with Abstracts, 19, p. 710.

1989. Upper Silurian reefal facies of the Memphremagog - Marbleton area, Eastern Townships, Québec Appalachians. In Reefs - Canada and Adjacent Areas. Edited by H.H.J. Geldsetzer, N.P. James and G.E. Tebbutt. Canadian Society of Petroleum Geologists, Memoir 13, pp. 306-315.

LaBBÉ, J.-Y. 1991. Géologie de la région de Weedon (Estrie). Ministère de l'Énergie et des Ressources du Québec, Et 88$05,50 \mathrm{p}$.

LabBé, J.-Y. and St-Julien, P. 1989. Failles de chevauchement acadiennes dans la région de Weedon, Estrie, Québec. Canadian Journal of Earth Sciences, 26, pp. 2268-2277.

Lavoie, D. 1985. Stratigraphie, géologie structurale, sédimentologie et paléo-milieux de la bande silurienne supérieure des lacs Aylmer et Saint-François. M.Sc. thesis, Laval University, Quebec City, 119 p.

Malo, M. and Bourque, P.-A. In press. Timing of deformation events from Late Ordovician to Mid-Devonian in the Gaspé Peninsula. In The Acadian Orogeny - recent studies in New England, Maritime Canada and the autochthonous foreland. Edited by D. Roy and S.J. Skehan. Geological Society of America, Special Volume 275.

Miall, A.D. 1978. Lithofacies types and vertical profile models in braided river deposits: a summary. In Fluvial sedimentology. Edited by A.D. Miall. Canadian Society of Petroleum Geology, Memoir 5, pp. 597-604.

Rust, B.R. and Koster, E.H. 1984. Coarse alluvial deposits. In Facies models. 2nd edition. Edited by R.G. Walker. Geoscience Canada, Reprint series 1, pp. 53-69.

Slivitzky, A. and St-Julien, P. 1987. Compilation géologique de la région de l'Estrie - Beauce. Ministère de l'Energie et des Ressources, Québec, MM 85-04, 40 p.

St-Julien, P. 1970. Géologie de la région de Disraèli (moitié est).
Comtés. de Frontenac, Wolfe et Mégantic. Ministère des Richesses Naturelles, Québec, Preliminary Report 587, 23 p.

St-Julien, P. and Hubert, C. 1975. Evolution of the Taconian orogen in the Quebec Appalachians. American Journal of Sciences, 275-A, pp. 337-362.

St-Julien, P., Slivitzky, A., and Feininoer, T. 1983. A deep structural profile across the appalachians of southern Quebec. Geological Society of America, Memoir 158, pp. 103-111.

Tremblay, A.B. 1989. The oceanic domain from Eastern Townships Appalachians, Québec: Taconian versus Acadian tectonics. In 1989 Quebec - Vermont Appalachian Workshop. Edited by M. Colpron and B. Doolan. Program with Abstracts, pp. 15-18.

1992a. Tectonic and accretionary history of Taconian oceanic rocks of the Quebec Appalachians. American Joumal of Sciences, 292, pp. 229-252.

1992b. Synthèse géologique de la région de Sherbrooke. Ministère de l'Énergie et des Ressources, Québec, Geological Report.

Tremblay, A.B., St-Julien, P., and Labbé, J.-Y. 1989a. Mise à l'évidence et cinématique de la faille de la Guadeloupe, Appalaches du sud du Québec. Canadian Journal of Earth Sciences, 26, pp. 1932-1943.

Tremblay, A.B., Hébert, R., and Bergeron, M. 1989b. Le complexe d'Ascot des Appalaches du sud du Québec: pétrologie et géochimie. Canadian Journal of Earth Sciences, 26, pp. 2407-2420.

Walker, R.G. 1984. Shelf and shallow marine sand. In Facies models, second edition. Edited by R.G. Walker. Geoscience Canada, Reprint Series 1, pp. 141-170.

Williams, H. (Compiler) 1978. Tectonic Lithofacies Map of the Appalachian Orogen. Memorial University of Newfoundland, Map No. 1, scale 1:2,000,000. 